финансово-хозяйственная операция, специалист-экономист, бухгалтерские документы.

\title{
FEATURES OF CARRYING OUT INVESTIGATORY INSPECTION IN THE PROCESS OF CRIMINAL BANKRUPTCY INVESTIGATION
}

\author{
Marushev A. D.
}

In connection with the increase of unemployment rate, the decline in profits of small and medium businesses there is an increasing number of cases on willful default on respective obligations and creating conditions for an enterprise bankruptcy by debtors. The paper defines the features of carrying out investigatory inspection of documents during investigation of crimes related to the criminal bankruptcy. Typical kinds of documents describing the kind of an economic activity of a bankrupt-company, flow of documents, the order of procedure accounting of business transactions are presented. The problematic issues connected with the application of documentary inspection methods in the course of inspection conducting, especially accounting documents are considered. The use of documentary methods allows revealing inconsistencies both in the content of a separate document, as well in the several interrelated documents. These methods include methods for identifying various inconsistencies or contradictions in the content of a particular document (formal, arithmetic and normative inspections), methods to identify inconsistencies in the contents of several interrelated (conjugate) documents (method of counter inspection and mutual control). The author notes that during inspection and preliminary study of the documents when investigating criminal bankruptcy, one should involve relevant specialists, especially a specialist-economist. Participation of a specialist-economist in the inspection of the documents is necessary to define the essence and the nature of the business transactions performed; the list of the documents whose inspection is required; correctness of a document issuance; transaction legality which is reflected in the document; good quality and poor quality of documents signs. Consequently, when investigating criminal bankruptcy, a large amount of documentation on the accounting and reporting is subjected to investigatory inspection and preliminary study. But, as the practice shows, all the documents received should be investigated in detail, noting features that characterize them as the material evidences.

Keywords: investigatory inspection, criminal bankruptcy, methods of research, debtor, intellectual forgery, material forgery, financial and business transaction, specialisteconomist, accounting documents.

УДК 343.98

Л. I. Керик, старший науковий співробітник НДІ вивчення проблем злочинності імені академіка В. В. Сташиса НАПрН України, кандидат юридичних наук

\section{РОЗСЛІДУВАННЯ ДОВЕДЕННЯ ДО САМОГУБСТВА: ПИТАННЯ ОРГАНІЗАЦІЇ ТА ПЛАНУВАННЯ}

Проаналізовано поняття та ознаки категорї «організація розслідування», взаємозв'язок понять "організачія» та «планування досудового розслідування». На підставі положень закону, підзаконних нормативно-

(C) Керик Л. І., 2016 
правових актів і наукових позииій учених-криміналістів запропоновано структуру організації розслідування доведення до самогубства та його планування, а також форму плану такого розслідування.

Ключові слова: організачія розслідування, планування розслідування, доведення до самогубства, план проведення досудового розслідування, версія.

Загальні проблеми організації розслідування досить широко висвітлені в криміналістичній літературі. Існують різні підходи до поняття «організація розслідування». М. І. Порубов зазначає, що якщо організація розслідування має свій предмет, мету, завдання, методологію, принципи й джерела, вона має право на існування як окремої наукової галузі права ${ }^{1}$. О. М. Ларін пропонує загальне визначення цього поняття як раціонального вибору, розтановки сил і знарядь, засобів, якими володіє слідчий, створення й використання оптимальних умов для досягнення цілей судочинства ${ }^{2}$. Л. О. СояСерко відносить до організації розслідування структуру слідчого апарату, підслідність, нагляд над слідством, комплекс прав і обов'язків слідчого та інших осіб, що беруть участь у провадженні слідства, матеріальне забезпечення роботи слідчих і їх обслуговування, організацію їх праціз новалова переконує, що організація розслідування - це планування, вибір слідчих дій та оперативно-розшукові заходи, їх поєднання, специфіка вирішення розумових завдань, використання науково-технічних засобів, економія процесуальних засобів ${ }^{4}$.

Зв'язок і співвідношення організації розслідування та криміналістичної методики розглядаються вченими-криміналістами по-різному. Так, М. П. Шаламов відносить організацію розслідування до змісту криміналістичної методики в цілому, не виділяючи ії як структурний елемент цього розділу криміналістики ${ }^{5}$.

При цьому в криміналістичній літературі досить глибоко висвітлено принципи організації розслідування. Необхідність високої організації роботи слідчого підкреслюють Л. М. Карнєєва і В. І. Ключанський, називаючи основними принципами організації розслідування дільничну систему та спеціалізацію 6 . Принцип оптимальної організованості слідчої дії як якісної підготовки до неї розглядають А. В. Дулов і П. Д. Нестеренко7.

${ }^{1}$ Див.: Порубов Н. И. Полвека с криминалистикой против криминала: записки старого криминалиста / Н. И. Порубов. - Минск : Тесей, 2007. - С. 215.

2 Див.: Ларин А. М. Расследование по уголовному делу. Планирование, организация / А. М. Ларин. - М. : Юрид. лит., 1970. - С. 59.

${ }^{3}$ Див.: Михайлов А. И. Научная организация труда следователя / А. И. Михайлов, Л. А. Соя-Серко, А. Б. Соловьев. - М. : Юрид. лит., 1974. - С. 8, 9.

${ }^{4}$ Див.: Коновалова В. E. К вопросу о принципах научной организации следственной деятельности / В. Е. Коновалова // Вопросы государства и права. - М., 1970. C. $340-341$.

5 Див.: Шаламов М. П. Некоторые проблемы советской криминалистики : монография / М. П. Шаламов. - М. : Юрид. лит., 1965. - С. 31.

6 Див.: Карнеева Л. М. Организация работы следователя : метод. пособие / Л. М. Карнеева, В. И. Ключанский. - М. : Госиздатюридлит, 1961. - 128 с.

7 Див.: Дулов А. В. Тактика следственных действий / А. В. Дулов, П. Д. Нестеренко. - Минск : Высш. шк., 1971. - С. 18. 
Найбільш доцільним, на нашу думку, є таке тлумачення поняття «організація розслідування»: це розроблення плану заходів місцевих органів кримінальної юстиції, взаємодія в процесі досудового розслідування (між слідчим, оперативними працівниками, спеціалістами, експертами), чіткий розподіл обов'язків між учасниками розслідування, кваліфіковане керівництво слідчо-оперативною групою або бригадою, наради слідчої групи, обмін інформацією та звітністю про результати роботи слідчої групи й кожного слідчого, необхідні умови праці, розроблення й виконання плану розслідування та інші організаційні заходи з успішного розкриття й розслідування злочину ${ }^{1}$.

Грунтуючись на досягненнях криміналістики, структуру організації розслідування доведення до самогубства можна уявити таким чином: 1) організація одержання вихідної інформації, порушення кримінальної справи; 2) визначення й конкретизація цілей і предмета розслідування й доказування; 3) визначення сил і засобів досягнення цілей розслідування; 4) його планування; 5) створення оптимальних умов для слідчих та інших дій; 6) мобілізація учасників розслідування для якісного виконання ними своїх функцій; 7) організація слідчих дій і тактичних операцій; 8) координація дій учасників розслідування; 9) взаємодія між слідчими органами та посадовими особами, які беруть участь у досудовому розслідуванні; 10) організація виявлення підозрюваного; 11) контроль за змістом, своєчасністю, активністю й результативністю дій усіх учасників розслідування².

За ст. 25 КПК України органи кримінальної юстиції зобов'язані в межах своєї компетенції розпочати досудове розслідування: а) у кожному випадку безпосереднього виявлення ознак кримінального правопорушення; б) у разі надходження заяви (повідомлення) про самогубство (повішення, утоплення, падіння з висоти та ін.), виявлення трупа з ознаками насильницької смерті; в) у разі зникнення людини за наявності обставин, що вказують на можливість доведення до самогубства. Обов'язком слідчого $є$ вжиття всіх передбачених законом заходів для встановлення події кримінального правопорушення й особи, яка його вчинила. Спочатку вирішуються такі завдання: відбулося саме самогубство чи стався нещасний випадок; це вбивство, інсценоване самогубством, чи є факти, що вказують на ознаки складу злочину, передбаченого ст. 120 КК України.

Належна організація та планування розслідування доведення до самогубства сприяють швидкому й ефективному їх розкриттю, що впливає на усунення складнощів під час розслідування. Результати проведеного нами анкетування слідчих МВС України показують, що 57,5 \% із них зазнають складнощів у своїй роботі. На поставлене запитання: «Чи вважаєте Ви за доцільне організовувати розслідування злочинів про доведення до самогубства?» - були отримані такі відповіді: так - 92,8 \% опитаних, ні - 7,2 \%3.

1 Див.: Шепитько В. Ю. Криминалистика : курс лекций / В. Ю. Шепитько. [Изд. 2-е, перераб. и доп.]. — Х. : Одиссей, 2005. — С. 153.

2 Див.: Там само. - С. 153.

3 Анкетування слідчих МВС України проводилося під час дії КПК України 1960 p. 
Під час організації розслідування доведення до самогубства треба враховувати: 1) наявність взаємодії між різними правоохоронними органами та спеціалістами ${ }^{1}$; 2) належне забезпечення слідчого (прокурора) організаційно-технічними, організаційно-тактичними та організаційно-методичними засобами розслідування.

Особливості взаємодії слідчих належать до числа вагомих складників організації розслідування. У криміналістичній літературі розглядаються різні аспекти такої взаємодії. Складність способів доведення до самогубства, що використовуються злочинцями, і встановлення причинного зв'язку між самогубством потерпілого й діями злочинця зумовлюють потребу приділяти взаємодії слідчих серйозну увагу. Про це також свідчать і результати проведеного нами анкетування слідчих МВС України, які вказують на необхідність комплексної (92,3 \%) організації проведення слідчих дій, організаційно-технічних та оперативно-розшукових заходів, і лише 6,8 \% респондентів переконані, що це треба здійснювати ізольовано.

Окремі слідчі МВС України під час анкетування надали слушні пропозиції з удосконалення досудового розслідування цього виду злочину, а саме: якісний збір матеріалів справи, покращення стану взаємодії слідчих та оперативних служб на стадії збирання речових доказів, документування в межах розслідування кримінальних справ цієї категорії, що допоможе поліпшити слідчу діяльність при розслідуванні доведення до самогубства.

Результати проведеного нами узагальнення кримінальних справ, порушених за ст. 120 КК України, показали, що розслідування проводилося слідчим одноосібно - у 97 \% випадках, слідчо-оперативною групою - лише $3 \%$, слідчою бригадою або різними слідчими не проводилося взагалі. На поставлене запитання: «Чи необхідна робота слідчо-оперативної групи при розслідуванні доведення до самогубства?» - були отримані такі відповіді: у всіх випадках - 85,5 \%; у цьому немає необхідності - 13,1 \%; вона потрібна за наявності достатніх даних, що вказують на факт і можлива в окремих випадках - лише 1,4 \%. 3 проведеного анкетування слідчих МВС України, нами зроблено висновок про доцільність проведення розслідування доведення до самогубства саме слідчо-оперативними групами, що пов'язано 3 необхідністю проведення системи пошукових дій із виявлення джерел інформації.

Слід зазначити, що проблемі взаємодії слідчого з обізнаними особами на досудовому етапі розслідування доведення до самогубства приділялося недостатньо уваги. Результати проведеного нами анкетування слідчих МВС України свідчать про те, що 51 \% респондентів призначають судові експертизи при розслідуванні злочину, передбаченого ст. 120 КК України. За результатами проведеного нами узагальнення кримінальних справ про доведення до самогубства, зроблено висновок, що допит експерта мав місце лише

${ }^{1}$ Див.: Про організацію діяльності органів досудового розслідування Міністерства внутрішніх справ України : наказ М-ва внутр. справ України від 09.08.2012 № 686 (зі змінами та допов.) [Електронний ресурс]. — Режим доступу : http://zakon2.rada. gov.ua/laws/show/z1770-12. 
в 6 \% випадків. Але ж у розслідуванні цих злочинів неабияку роль відіграють саме своєчасно призначені й проведені судово-медична, судово-психіатрична, судово-психологічна й криміналістичні експертизи.

В організації розслідування доведення до самогубства необхідно враховувати належне забезпечення слідчого (прокурора): а) організаційно-технічними засобами розслідування; б) організаційно-тактичними засобами розслідування; в) організаційно-методичними засобами розслідування.

Організаційно-технічне забезпечення слідчого під час розслідування розглядуваного злочину є обмеженим. Уважаємо, що треба розробити алгоритм застосування різними суб'єктами кримінально-процесуальної й оперативно-розшукової діяльності науково-технічних засобів у типових ситуаціях доведення до самогубства. На етапі підготовки до проведення слідчої дії мають вирішуватися такі організаційні питання, як залучення спеціалістів та оперативних співробітників, форми взаємодії між ними, забезпечення необхідними науково-технічними засобами.

Питання забезпечення слідчого організаційно-тактичними засобами розслідування злочину, передбаченого ст. 120 КК України, полягає в тому, що за цією категорією злочинів потрібно вирішувати специфічні тактичні завдання. Зокрема, В. С. Корноухов називає такі тактичні завдання: а) «виключення самогубства як роду смерті» (отримана в ході вирішення цього завдання система доказів спростовує самогубство й не дозволяє підозрюваному посилатися на обставини, що його виправдовують); б) «доказування способу й мотиву доведення до самогубства» ${ }^{1}$.

Проблема забезпечення слідчого організаційно-методичними засобами розслідування доведення до самогубства полягає у відсутності належних методичних рекомендацій з розслідування злочинів цієї категорії, що могли б належним чином допомогти слідчому.

Деякі аспекти планування розслідування розглядались окремими вченими-криміналістами. Так, ними було визначено: поняття й зміст планування, його принципи, види, умови, завдання, етапи, форми та ін. В. І. Громов, наприклад, розглядає планування як теорію розслідування злочинів, побудовану на теоретичних засадах криміналістики. С. О. Голунський окреслює цілі, умови й принципи планування та наголошує на його специфіці при розслідуванні різних категорій кримінальних справ і на різних етапах планування. Він пропонує трактування поняття «планування» як комплекс взаємозалежних стадій, де перша - це висунення слідчих версій, друга - визначення по кожній із висунутих версій кола тих питань, які треба з'ясувати з метою перевірки версій; третя - перелік кола слідчих дій, необхідних для досягнення намічених питань, четверта - визначення строків виконання кожної з передбачуваних слідчих дій․ О. М. Васильєв формулює плануван-

${ }^{1}$ Див.: Курс криминалистики : Особенная часть. Т. 1: Методика расследования насильственных и корыстно-насильственных преступлений / отв. ред. В. Е. Корноухов. - М. : Юристъ, 2001. - С. 349, 361.

2 Див.: Криминалистика. Техника и тактика расследования преступлений / [Н. А. Бобров, А. И. Винберг, С. А. Голунский, В. И. Громов и др.] ; под ред. А. Я. Вышинского. - М. : Юрид. изд-во НКЮ СССР, 1938. - С. 329-337. 
ня розслідування як побудований на наукових засадах метод розслідування злочинів, що складається із планомірного й цілеспрямованого збирання доказів із використанням сучасних тактичних прийомів і науково-технічних засобів ${ }^{1}$. В. О. Коновалова визначає планування розслідування як програму останнього, що може бути уявною або мати певну форму².

С. О. Голунський зробив також спробу сформулювати принципи планування. До принципів планування розслідування вчений відносить: 1) при плануванні завжди слід виходити з оцінювання політичного значення злочину й аналізу тієї соціально-політичної обстановки, у якій він був учинений; 2) план слід будувати так, щоб забезпечити швидкість збирання основного доказового матеріалу; 3) план повинен передбачити збирання матеріалу, який давав би відповідь на запитання семичленної римської формули; 4) усе розслідування може бути поділене на дві основні частини, які можна умовно назвати загальним і спеціальним розслідуванням (до і після пред’явлення конкретній особі обвинувачення).

Досить цікаву позицію щодо принципів планування розслідування запропонував О. Н. Колесниченко. До них науковець відніс індивідуальність, обгрунтованість, динамічність, де: а) принцип індивідуальності - це усунення шаблону, складання плану щодо обставин події злочину з урахуванням його окремої характеристики в кожному випадку; б) принцип обгрунтованості - при плануванні слід виходити 3 конкретної доказової інформації, обгрунтовуючи елементи плану конкретними даними, які $є$ в розпорядженні слідчого. Обгрунтованість плану випливала з аргументованості версій як необхідної передумови планування ${ }^{3}$.

Планування розслідування передбачає формулювання шляхів і способів останнього, коли встановлюються обставини, що підлягають з'ясуванню в кримінальній справі, визначається система слідчих дій та оперативно-розшукових заходів, їх зміст, послідовність проведення і строки виконання ${ }^{4}$.

Слід наголосити, що плануванню розслідування доведення до самогубства вченими-криміналістами не приділялося достатньої уваги. 3 цього погляду воно має складатися з аналізу й оцінювання первинної інформації в існуючій слідчій ситуації, розроблення версій і організації їх перевірки, визначення обставин, що підлягають установленню.

Складання плану розслідування передбачає планування черговості проведення окремих слідчих дій та їх планування. Так, при підготовці до проведення таких слідчих дій, як допит, обшук, слідчий (прокурор) планує їх проведення, обираючи найоптимальніші прийоми здійснення. Планування

${ }^{1}$ Див.: Васильев А. Н. Планирование расследования преступлений / А. Н. Васильев, Г. Н. Мудьюгин, Н. А. Якубович ; под ред. С. А. Голунского. - М. : Юрид. лит., 1957. - 199 с.

2 Див.: Коновалова В. Е. К вопросу о принципах научной организации следственной деятельности. - С. 125-142.

${ }^{3}$ Див.: Колесниченко А. Н. Научные и правовые основы расследования отдельных видов преступлений : автореф. дис. на соискание уч. степени д-ра юрид. наук : спец. 717 «Криминалистика» / А. Н. Колесниченко. — Х., 1967. — 21 с.

4 Див.: Шепитько В. Ю. Указ. праця. - С. 154. 
розслідування пронизує всю діяльність слідчого, є одночасно його організуючою серцевиною ${ }^{1}$.

Висунення й перевірка версій відіграє вирішальну роль і становить основу планування. Розроблення вчення про слідчу (криміналістичну) версію розпочалося з визначення самого поняття «версія». Так, О. М. Васильєв характеризує слідчу версію як індуктивний висновок слідчого у формі припущення, яке грунтується на фактичних даних про подію злочину та його окремих обставин, що підлягає перевірці за логічними правилами дедукції². О. М. Ларін розглядає слідчу версію як інтегральну ідею, що будується 3 метою встановлення об'єктивної істини в справі, як образ, що несе функцію моделі створених уявою досліджуваних обставин і містить припустиму оцінку наявних даних, які стають поясненням останніх і виражаються у формі гіпотези ${ }^{3}$ Р. С. Бєлкін сформулював криміналістичну версію як обгрунтоване припущення щодо окремого факту або групи фактів, які мають або можуть мати значення в справі, указують на наявність цих фактів і пояснюють їх походження, взаємозв'язок і зміст з метою встановлення об'єктивної істини ${ }^{4}$. Я. Пещак визначає поняття «слідча версія» як припущення слідчого, що є обгрунтованим зібраним матеріалом, про форми зв'язку і причини окремих (або в цілому) явищ розслідуваної події, як одне з можливих пояснень установлених до цього часу фактів та обставин справи ${ }^{5}$. В. О. Коновалова вважає слідчу версію найбільш значимою для проблем розслідування ніж експертну, судову та розшукову, а за характером $є$ більш об'ємною та об'єднуючою розшукову й експертну версії́.

Висування при розслідуванні злочинів слідчих версій за аналогією може призвести до позитивних результатів. Джерелами аналогії під час створення версії можуть бути: а) оперативні й слідчі дані стосовно розкритих злочинів подібних за складом і методами їх учинення; б) оперативні й слідчі матеріали щодо однотипових нерозкритих злочинів; в) загальні теоретичні положення, що грунтуються на узагальненні слідчої практики й дозволяють накреслити певну кількість версій з конкретної категорії справ; г) теоретичні знання й особистий досвід слідчого в розслідуванні

${ }^{1}$ Див.: Хань Г. А. Теоретичні засади планування та організації розслідування злочинів : автореф. дис. на здобуття наук. ступеня канд. юрид. наук : спец. 12.00.09 «Кримінальний процес та криміналістика; судова експертиза» / Г. А. Хань. - Х., 2007. - $20 \mathrm{c}$.

2 Див.: Васильев А. Н. Планирование следствия и разработка следственных версий / А. Н. Васильев // Вопр. сов. криминалистики (Рефераты всесоюз. науч. совещания по криминалистике). - Алма-Ата : Казах. гос. ун-т, 1959. - С. 17-26.

3 Див.: Ларин А. М. От следственной версии к истине / А. М. Ларин. - М., 1976. - С. 29-33.

${ }^{4}$ Див.: Белкин Р. С. Курс криминалистики : учеб. пособие / Р. С. Белкин. - [3-е изд., доп.]. - М. : ЮНИТИ-ДАНА» : Закон и право, 2001. - С. 493.

5 Див.: Пещзак Я. Следственные версии. Криминалистическое исследование / Я. Пещак. - М. : Прогресс, 1976. - С. 132.

${ }_{6}$ Див.: Коновалова В. E. Версия: концепции и функции в судопроизводстве : монография / В. Е. Коновалова. - Х. : Изд. Н. Н. Вапнярчук, 2007. - С. 72-78. 
злочинів. Тут вагомого значення набуває аналіз способу вчинення злочину, тому що спосіб - це та чітка сторона злочину, у якій можна найшвидше знайти аналогічне ${ }^{1}$.

У криміналістичній літературі сформульовані тактичні правила висунення версій, їх класифікація, їх значення в розслідуванні злочинів, відзначена їх роль як основного інструмента криміналістичного й процесуального пізнання. Проблема класифікації криміналістичних версій розглядалась окремими вченими-криміналістами. Так, Р. С. Бєлкін запропонував таку класифікацію криміналістичних версій: 1) за суб'єктом висунення - версії слідчі (їх різновид - розшукові), оперативно-розшукові, судові, експертні; 2) за обсягом - загальні й окремі; 3) за ступенем визначеності - типові й конкретні ${ }^{2}$. Г. В. Арцишевський поділяє слідчі версії на: а) перевірочні - залежно від того, чи $€$ на момент їх висунення дані, що дозволяють підозрювати конкретну особу; б) пошукові - якщо таких даних немає; в) проміжні й завершальні - залежно від того, чи охоплюється висунутим припущенням слідчого всі або частина основних обставин, що підлягають доказуванню, та ін. ${ }^{3}$ О. Ф. Реховський до класифікації криміналістичних версій відносить такі: за обсягом (одиничні); за ступенем конкретності (типові й конкретні); за ступенем імовірності (малоймовірні й більш імовірні); за ступенем побудови (першочергові й наступні) ${ }^{4}$.

Поряд із слідчими (криміналістичними) версіями вчені вирізняють типові, що мають іншу природу походження та фактичну базу формування. О. В. Синчук уважає, що типові версії посідають особливе місце, оскільки виникають на підставі даних, віддзеркалених у криміналістичній характеристиці, що застосовуються в процесі організації й планування розслідування, призводячи до оптимального набору слідчих дій та оптимальної черговості їх запровадження, з метою вплинути на виникаючі слідчі ситуації.

Типова версія $є$ інформаційною моделлю, у якій відображені засновані на спостереженнях і узагальненнях позитивні знання, що надають найімовірніше пояснення події злочину в цілому чи ії окремих сторін відповідно до певних слідчих ситуацій. Формування типових версій може відбуватися:

1 Див.: Коновалова В. Е. О роли логики в построении следственных версий // Учен. записки. - Вып. 16: Вопросы уголов. права, уголов. процесса и криминалистики. - Х. : Харьк. юрид. ин-т, 1962. - С. 103-110.

2 Див.: Белкин Р. С. Указ. праця. - С. 484, 493.

3 Див.: Арцишевский Г. В. Выдвижение и проверка следственных версий : монография / Г. В. Арцишевский. - М. : Юрид. лит., 1978. - С. 20.

${ }_{4}$ Див.: Реховский А. Ф. Проблемы криминалистической версии : автореф. дис. на соискание уч. степени канд. юрид. наук : спец. 12.00 .09 «Уголовный процесс; криминалистика, судебная экспертиза, оперативно-розыскная деятельность» / А. Ф. Реховский. - Свердловск, 1989. - С. 11.

5 Див.: Синчук O. В. Типові версії в структурі криміналістичної методики : автореф. дис. на здобуття наук. ступеня канд. юрид. наук : спец. 12.00.09 «Кримінальний процес та криміналістика; судова експертиза; оперативно-розшукова діяльність» / О. В. Синчук. - Х., 2010. - С. 9. 
а) у традиційний спосіб - на підставі даних узагальненого характеру, включаючи положення криміналістики й результати судово-слідчої практики і б) новаторський - на підставі використання статистичних методів дослідження та насамперед за рахунок виявлення й використання ймовірно-статистичних і кореляційних зв'язків між елементами криміналістичної характеристики певного різновиду злочинів.

Результати проведеного нами анкетування слідчих МBC констатують, що слідчими версіями, притаманними розслідуванню доведення до самогубства, можуть бути такі: 1) мало місце доведення до самогубства (71,5 \%); 2) мало місце самогубство потерпілої особи $(41,2 \%) ; 3)$ стався нещасний випадок $(35,3 \%) ; 4)$ учинено інший злочин $(24,9 \%) ; 5)$ надійшла неправдива заява й злочину взагалі не було $(9 \%) ; 6)$ версія про мотив учинення злочину й особи, яка довела потерпілого до самогубства, та хто був зацікавлений у смерті потерпілого (0,9\%).

Версії про доведення до самогубства мають свої специфічні риси й не можуть охоплювати тільки традиційний перелік версій. Залежно від особи потерпілого, особи злочинця, механізму вчинення злочину, вони можуть видозмінюватися. Для будь-якої версії певне значення мають дані аналізу вихідного матеріалу, який допомогає іiі формуванню. Отже, відповідно до елементів криміналістичної характеристики слідчі версії про доведення до самогубства можуть поділятися на декілька видів: 1) версії про суть події, що відбулася; 2) версії щодо жертви; 3) версії про особу злочинця.

Після визначення можливих версій у розслідуваній справі, слідчий (прокурор) повинен скласти письмовий план розслідування. Його складання $\epsilon$ початком організаційної роботи слідчого в справі. Під час розслідування необхідно використовувати форму письмового плану, у якій відображені: 1) слідчі версії; 2) обставини, що підлягають з'ясуванню; 3) слідчі дії та оперативно-розшукові заходи; 4) строки їх виконання; 5) виконавці; 6) примітки. Взаємовідносини потерпілого й підозрюваного $є$ центральним питанням плану розслідування (ознакою об'єктивної сторони цього злочину $є$ самогубство або замах на нього потерпілого та встановлення причинного зв'язку між діями винного й наслідками, що настали).

У процесі розслідування доведення до самогубства потрібно виходити 3 предмета доказування в кримінальній справі. Наведемо далі обставини, що підлягають з'ясуванню в зазначених справах, це: а) обставини події злочину; б) час, місце та обстановка злочину; в) особа потерпілого (жертви); г) особа злочинця; г) механізм доведення до самогубства; д) наявність (відсутність) ознак інсценування; д) спосіб учинення самогубства; е) наявність чи відсутність передсмертної записки.

Отже, під час організації розслідування доведення до самогубства необхідно враховувати: 1) наявність взаємодії між різними правоохоронними органами та спеціалістами; 2) належне забезпечення слідчого (прокурора) організаційно-технічними, організаційно-тактичними та організаційно-методичними засобами розслідування. 


\title{
РАССЛЕДОВАНИЕ ДОВЕДЕНИЯ ДО САМОУБИЙСТВА: ВОПРОСЫ ОРГАНИЗАЦИИ И ПЛАНИРОВАНИЯ
}

\begin{abstract}
Керик Л. И.
Проанализированы понятие и признаки категории «организация расследования», взаимосвязь понятий «организация» и «планирование досудебного расследования». На основании положений закона, подзаконных нормативно-правовых актов и научных позиций ученых-криминалистов предложена структура организации расследования преступлений по доведению до самоубийства и его планирование, а также форма плана такого расследования.
\end{abstract}

Ключевые слова: организация расследования, планирование расследования, доведение до самоубийства, план проведения досудебного расследования, версия.

\section{INVESTIGATION ON DRIVING TO SUICIDE: ORGANIZATION AND PLANNING}

Keryk L. I.

The paper analyzes the notion and the features of the «organization of the investigation» category, the relationship of the concepts of "organization» and "planning of the pre-trial investigation». On the basis of the provisions of the law, subordinate normative and legal acts and the scientific positions of criminalistic scientists the organization structure of crimes investigation on driving to suicide and its planning, as well the form of a plan of such an investigation is suggested. The organization structure of crimes investigation of the driving to suicide may be represented as follows: organization of receiving initial information; definition and concretization of purposes and the subject-matter of the investigation and evidence; definition of the forces and means of achieving purposes of the investigation; its planning; creating optimal conditions for investigators and other actions; mobilization of the investigation participants for the qualitative performance of their functions; organization of the investigatory actions and tactical operations; coordination of the participants actions in the investigation; interaction between the bodies of inquiry and officials who participate in the pre-trial investigation; organization of the suspect detection; control over the content, timeliness, activity and effectiveness of the actions of all participants in the investigation. At the stage of the preparation for the investigative action such organizational issues as involvement of specialists and operational employees, forms of interaction between them, providing with necessary scientific and technical means, should be resolved. Circumstances which are subjected to the clarification on the cases of driving to suicide, are: event of the crime; time, place and situation of the crime; personality of injured (victim), personality of the offender; mechanism of the driving to suicide; presence (absence) of staging signs; method of committing suicide; presence or absence of a suicide note.

Keywords: organization of the investigation, investigation planning, driving to suicide, plan of carrying out pretrial investigation, version. 